\title{
Rickettsia-like-organisms and phytoplasmas associated with diseases in Australian strawberries
}

\author{
Claire Streten $^{\mathrm{A}, \mathrm{D}}$, Geoff K. Waite ${ }^{\mathrm{B}}$, Mark E. Herrington ${ }^{\mathrm{B}}$, Don G. Hutton ${ }^{\mathrm{B}}$, Denis M. Persley ${ }^{\mathrm{C}}$ \\ and Karen S. Gibb ${ }^{\mathrm{A}}$ \\ ${ }^{\text {A }}$ Charles Darwin University, Darwin, NT 0909, Australia. \\ ${ }^{B}$ Department of Primary Industries and Fisheries, Horticulture and Forestry Science, Maroochy Research Station, \\ Nambour, Qld 4560, Australia. \\ ${ }^{\mathrm{C}}$ Department of Primary Industries and Fisheries, Horticulture and Forestry Science, 80 Meiers Road, Indooroopilly, \\ Brisbane, Qld 4068, Australia. \\ ${ }^{D}$ Corresponding author. Email: claire.streten@cdu.edu.au
}

\begin{abstract}
Strawberry lethal yellows (SLY) disease in Australia is associated with the phytoplasmas Candidatus Phytoplasma australiense and tomato big bud, and a rickettsia-like-organism (RLO). Ca. P. australiense is also associated with strawberry green petal (SGP) disease. This study investigated the strength of the association of the different agents with SLY disease. We also documented the location of SLY or SGP plants, and measured whether they were RLO or phytoplasma positive. Symptomatic strawberry plants collected from south-east Queensland (Australia) between January 2000 and October 2002 were screened by PCR for both phytoplasmas and the RLO. Two previously unreported disease symptoms termed severe fruit distortion (SFD) and strawberry leaves from fruit (SLF) were observed during this study but there was no clear association between these symptoms and phytoplasmas or the RLO. Only two SGP diseased plants were observed and collected, compared with 363 plants with SLY disease symptoms. Of the 363 SLY samples, 117 tested positive for the RLO, 67 tested positive for $\mathrm{Ca}$. P. australiense AGY strain and 11 plants tested positive for $\mathrm{Ca}$. P. australiense PYL variant strain. On runner production farms at Stanthorpe, Queensland the RLO was detected in SLY diseased plants more frequently than for the phytoplasmas. On fruit production farms on the Sunshine Coast, Queensland, $C a$. P. australiense was detected in SLY disease plants more frequently than the RLO.
\end{abstract}

Additional keywords: Candidatus Phytoplasma australiense, strawberry lethal yellows, strawberry green petal.

\section{Introduction}

Commercial strawberry (Fragaria $\times$ ananassa) farms are located throughout south-east Queensland, Australia. Plants are produced as runners that are taken from mother plants located on runner production farms. The mother plants originate as runners from foundation strawberry plants maintained in tissue culture, and then grown in fumigated soil for 12 months in the Stanthorpe area, where the climate provides necessary chilling of the runners. The runner material from Stanthorpe is uprooted in March or April, and distributed to fruit production farms in the Nambour, Caboolture, Brisbane and Beenleigh districts in south-east Queensland and to the Atherton Tableland in north Queensland. The fruit is grown throughout north Queensland and south-east Queensland from April to October.

Strawberry plants grown on these runner and fruit production farms are affected by a range of diseases such as strawberry lethal yellows (SLY), strawberry green petal (SGP), yellow edge (SYE), strawberry crinkle (SC), Fusarium wilt and crown rot (Broadley et al. 1988). Of these diseases, SLY and SGP are caused by intracellular bacteria-like pathogens that can have a significant impact on productivity because flowering and fruit set are inhibited, and infected plants frequently die (Greber and Gowanlock 1979). These diseases can be transmitted from mother plants to runners and so can be passed in planting material from runner production farms to fruit production areas (Greber 1987). To prevent this, plants exhibiting symptoms are rogued from runner beds during frequent disease inspections. However, it can take up to 8 weeks for the plants to exhibit SLY or SGP symptoms (Greber and Gowanlock 1979) making it possible for affected runners to be unintentionally sent to fruit production farms.

Two types of lethal yellows symptoms have been reported in Australian strawberry plants. Bronze discoloration of older leaves, stunted petioles and interveinal chlorosis on 
younger leaves are symptoms associated with a rickettsialike-organism (RLO) (Greber and Gowanlock 1979). Purple discoloration of older leaves, and stunted younger leaves with shortened petioles and marginal chlorosis are associated with Candidatus Phytoplasma australiense (Padovan et al. 2000; Greber and Gowanlock 1979). The symptoms associated with both these organisms are collectively referred to as SLY disease. However, another disease syndrome called SGP has also been associated with $C a$. P. australiense. This disease is characterised by severe phyllody where floral structures become leaf-like. In addition, a mixed phytoplasma association of an uncharacterised phytoplasma and $\mathrm{Ca}$. P. australiense has also been identified in association with SLY symptoms (Padovan et al. 2000).

The relationship between these different organisms and SLY disease is poorly understood because it is difficult to differentiate the symptoms associated with an RLO from those associated with a phytoplasma (Greber and Gowanlock 1979). Although SLY diseased samples could be tested using PCR primers specific for the phytoplasma 16S rRNA gene or the Tu elongation factor (tuf) gene (Padovan et al. 2000), a diagnostic test for the SLY RLO has not been available. The recent characterisation of the flavoprotein subunit succinate dehydrogenase gene of the RLO associated with papaya bunchy top (PBT) disease and the development of PCR primers to detect this RLO (Davis et al. 1998) may provide the tools to investigate the significance of each of the causal agents associated with SLY (Streten et al., unpublished data). This study aimed to investigate the relationship between phytoplasmas, RLOs and SLY disease, and the distribution of these organisms in the runner and fruit production areas.

\section{Methods}

Plant sample collection sites

Asymptomatic and symptomatic strawberry plants were collected from various locations in Queensland and South Australia between March 2000 and October 2002 (Table 1). Diseased plants were collected if they exhibited abnormal growth or discoloration compared with healthy plants.

\section{Reference phytoplasma samples}

The reference sample for tomato big bud phytoplasma was extracted from a symptomatic periwinkle plant and the reference strain for Candidatus Phytoplasma australiense Australian grapevine yellows (AGY) was extracted from a papaya plant with dieback symptoms. Both were collected in Darwin. The Candidatus Phytoplasma australiense Phormium yellow leaf (PYL) reference strain DNA was provided by Mark Andersen (HortResearch, Auckland, New Zealand).

\section{Screening for phytoplasmas and RLOs}

Approximately $10 \mathrm{~mm}$ of the strawberry petioles was used as source material for DNA extraction. The petioles were cut into 1-mm sections and total DNA extracted according to the Doyle and Doyle (1990) CTAB protocol with the modification that the CTAB extraction buffer $(2 \%$ CTAB, $1.4 \mathrm{~m} \mathrm{NaCl}, 20 \mathrm{~mm}$ EDTA, 1\% PVP) contained $1 \mathrm{~m}$ Tris- $\mathrm{HCl}$ (Padovan et al. 1995). Extracted DNA was separated on a 1\% agarose gel stained with ethidium bromide and visualised by UV trans-illumination to provide an indication of DNA quality.

Symptomatic samples were initially tested using the fP1/rP7 (Schneider et al. 1995; Deng and Hiruki 1991) primer pair, which amplifies the 16S rRNA gene and 16S-23S spacer region of most phytoplasmas. Samples that tested negative using these primers were tested again in a single round PCR using the primer pair fU5 $/ \mathrm{m} 23 \mathrm{sr}$ (Lorenz et al. 1995; Padovan et al. 1995). This primer pair amplifies a smaller region of the phytoplasma 16S rRNA gene and can be more suitable than P1/P7 for amplifying phytoplasmas from difficult hosts (Schneider and Gibb 1997). The PCR reactions were according to Schneider et al. (1997), with 35 cycles of $95^{\circ} \mathrm{C} / 1 \mathrm{~min} ; 55^{\circ} \mathrm{C} / 1 \mathrm{~min}$ and $72^{\circ} \mathrm{C} / 1.5 \mathrm{~min}$. One $\mu \mathrm{L}$ of undiluted DNA, $1: 10$ diluted DNA or $1: 50$ diluted DNA was used in PCR reactions.

Samples were also screened using the fTufAy/rTufAy primers, which amplify the Tu elongation factor (tuf) gene of $\mathrm{Ca}$. P. australiense (Schneider et al. 1997). PCR reactions were according to Schneider et al. (1997) with 35 cycles of $95^{\circ} \mathrm{C} / 1 \mathrm{~min} ; 50^{\circ} \mathrm{C} / 1 \mathrm{~min}$; $72^{\circ} \mathrm{C} / 1.5 \mathrm{~min}$.

Diseased strawberry samples were also tested using PCR primers (PBTF1 and PBTR1), which amplify the flavoprotein subunit of the succinate dehydrogenase $(s d h A)$ gene of the RLO associated with papaya bunchy top disease (Davis et al. 1998). PCR reactions were according to Davis et al. (1998) with 40 cycles of $94^{\circ} \mathrm{C} / 1 \mathrm{~min}$; $52^{\circ} \mathrm{C} / 1.5 \mathrm{~min}$ and $72^{\circ} \mathrm{C} / 1 \mathrm{~min}$. Deoxyribonucleic acid from healthy strawberry plants was included as a negative control. The PCR products amplified from two SLY diseased samples using the PBTF1/PBTR1 primers were purified using QIAquick PCR purification kit. All steps were performed according to the manufacturer's protocol (Qiagen, Brisbane, Australia). Deoxyribonucleic acid quantity was determined by comparing purified products to a DNA mass ladder (Invitrogen, Mount Waverley, Victoria). The PCR products were sequenced using the big dye terminator sequencing kit version 3.1 and sequencing reactions were separated at Australian Genomic Research Facility (AGRF) (Brisbane, Australia).

Nucleotide sequences were aligned using AssemblyLIGN (Eastman Kodak Co., New Haven, CT, USA). The BlastN search engine (Altschul et al. 1997) was used to identify homologous sequences in the GenBank main database which was accessed through the Biomanager website (Entigen Corporation, http://www.entigen.com, Sydney, Australia).

\section{Identification of phytoplasmas and RLOs}

The PCR products amplified using primers specific for the phytoplasma 16S rRNA gene were digested with restriction enzymes $A l u \mathrm{I}$ and RsaI, and the tuf gene PCR products were digested with HpaII and HindIII (Schneider et al. 1997). PCR products of samples previously identified as being associated with $\mathrm{Ca}$. P. australiense or the TBB phytoplasma were used as references for restriction fragment length polymorphic (RFLP) analysis. The PCR products amplified using the primers specific for the RLO $s d h A$ gene were digested with $A l u \mathrm{I}$, RsaI, HpaII and MseI. A SLY diseased sample that was identified as RLO positive by sequence analysis was used as the reference strain for RLO sdhA gene RFLP analysis. Digestion reactions were performed according to the manufacturer's specifications (Promega, Sydney, Australia). The digested products were separated on a $12 \%$ polyacrylamide gel, which was then stained with ethidium bromide and bands visualised under UV illumination.

\section{Relationship between the presence of phytoplasmas or RLO}

The relationship between phytoplasmas or RLO and SLY diseased plants was analysed using Fisher's exact test. Statistical analysis was performed using JMP software version 5.0.1 (SAS Institute Inc., North Carolina, USA). 
Table 1. Collection data for strawberry plant samples collected between March 2000 and October 2002

\begin{tabular}{|c|c|c|c|c|c|}
\hline $\begin{array}{l}\text { Collection } \\
\text { area }\end{array}$ & Farm type & Location & Date & $\begin{array}{c}\text { Presence or } \\
\text { absence of } \\
\text { symptoms } \\
(+/-)\end{array}$ & $\begin{array}{l}\text { Number } \\
\text { collected }\end{array}$ \\
\hline \multirow[t]{8}{*}{1} & \multirow[t]{8}{*}{ Runner } & \multirow{8}{*}{$\begin{array}{l}\text { Stanthorpe, Queensland } \\
\quad\left(28^{\circ} \mathrm{S}, 151^{\circ} \mathrm{E}\right)\end{array}$} & Mar-00 & $+(\mathrm{SLY})$ & 36 \\
\hline & & & Feb-01 & - & 34 \\
\hline & & & & $+(\mathrm{SLY})$ & 5 \\
\hline & & & Mar-01 & + (SLY) & 64 \\
\hline & & & Мay-01 & + (SLY) & 10 \\
\hline & & & Jun-01 & $+(\mathrm{SLF})$ & 20 \\
\hline & & & Feb-02 & + (SLY) & 25 \\
\hline & & & Mar-02 & + (SLY) & 20 \\
\hline \multirow[t]{24}{*}{2} & \multirow[t]{24}{*}{ Fruit } & \multirow{7}{*}{$\begin{array}{l}\text { Caboolture, Queensland } \\
\quad\left(27^{\circ} \mathrm{S}, 152^{\circ} \mathrm{E}\right)\end{array}$} & May-00 & + (SLY) & 25 \\
\hline & & & Jul-00 & + (SLY) & 8 \\
\hline & & & May-01 & $+(\mathrm{SLY})$ & 52 \\
\hline & & & May-02 & $+(\mathrm{SLY})$ & 14 \\
\hline & & & Jun-02 & + (SLY) & 3 \\
\hline & & & Aug-02 & $+(\mathrm{SLY})$ & 46 \\
\hline & & & & $+(\mathrm{SLY}+\mathrm{SGP})$ & 4 \\
\hline & & \multirow{9}{*}{$\begin{array}{l}\text { Nambour, Queensland } \\
\quad\left(26^{\circ} \mathrm{S}, 152^{\circ} \mathrm{E}\right)\end{array}$} & Jul-00 & $+(\mathrm{SLY})$ & 5 \\
\hline & & & Aug-00 & + (SLY) & 23 \\
\hline & & & Apr-01 & - & 74 \\
\hline & & & Jul-01 & - & 3 \\
\hline & & & & + (SGP) & 2 \\
\hline & & & May-02 & + (SLY) & 4 \\
\hline & & & Jun-02 & + (SLY) & 1 \\
\hline & & & Aug-02 & $+(\mathrm{SLY})$ & 9 \\
\hline & & & & $+(\mathrm{SLY}+\mathrm{SGP})$ & 4 \\
\hline & & \multirow{4}{*}{$\begin{array}{l}\text { Beenleigh, Queensland } \\
\quad\left(27^{\circ} \mathrm{S}, 153^{\circ} \mathrm{E}\right)\end{array}$} & Aug-00 & $+(\mathrm{SLY})$ & 2 \\
\hline & & & Jul-01 & $+(\mathrm{SLY})$ & 1 \\
\hline & & & Jun-02 & $+(\mathrm{SLY})$ & 5 \\
\hline & & & & $+(\mathrm{SLY}+\mathrm{SGP})$ & 2 \\
\hline & & \multirow{2}{*}{$\begin{array}{l}\text { Brisbane, Queensland } \\
\quad\left(27^{\circ} \mathrm{S}, 153^{\circ} \mathrm{E}\right)\end{array}$} & Sep-00 & $+(\mathrm{SFD})$ & 6 \\
\hline & & & & - & 3 \\
\hline & & $\begin{array}{l}\text { Atherton, Queensland } \\
\qquad\left(17^{\circ} \mathrm{S}, 145^{\circ} \mathrm{E}\right)\end{array}$ & Jun-01 & $+(\mathrm{SFD})$ & 1 \\
\hline & & $\begin{array}{l}\text { Adelaide, South Australia } \\
\qquad\left(34^{\circ} \mathrm{S}, 138^{\circ} \mathrm{E}\right)\end{array}$ & Dec-01 & $+(\mathrm{SLY})$ & 5 \\
\hline
\end{tabular}

\section{Results}

The nucleotide sequences of the PCR product amplified from the two representative SLY samples using the PBTF1 and PBTR1 primers were homologous to each other and shared $96 \%$ homology with the $s d h A$ gene of the RLO associated with papaya bunchy top disease (AY423625).

Strawberry plants exhibited a range of disease symptoms, lethal yellows (SLY), green petal (SGP), fruit distortion (SFD) and leaves emerging from fruit (SLF) (Table 2). Of these diseases, SLY occurred most frequently. SLY diseased plants exhibited bronze, red and purple discoloration on older leaves, and stunted younger leaves with shortened petioles, marginal and interveinal chlorosis.

Of the 363 SLY plants tested, 211 were PCR positive and of these, 117 were RLO positive, 83 were phytoplasma positive and 11 were positive for both (Table 2). All samples that tested positive for an RLO had the same RFLP pattern as the reference RLO when digested with RsaI, HpaI, AluI or MseI (Fig. 1).

The 83 phytoplasmas detected by the universal PCR test were subjected to the $C a$. P. australiense specific PCR test using the $t u f$ gene primer pair. This product was subjected to RFLP analysis which showed that two strains were present; one was indistinguishable from the $C a$. P. australiense Australia grapevine yellows (AGY) strain reference sample and the other indistinguishable from $\mathrm{Ca}$. P. australiense Phormium yellow leaf (PYL) strain reference sample based on HpaII digestion but differed based on HindII banding patterns (data not shown). RFLP analysis of the 16S rRNA gene showed that the TBB phytoplasma was also associated with SLY disease (data not shown). Of the 83 samples positive for phytoplasma, $\mathrm{Ca}$. P. australiense was detected most often (Table 2). Some mixed infections were detected; RLO with $C a$. P. australiense AGY strain and TBB 
Table 2. The relationship between symptoms expressed by strawberry plants collected between March 2000 and October 2002 and the associated agents

\begin{tabular}{|c|c|c|c|c|c|c|c|c|}
\hline \multirow[t]{2}{*}{ Symptoms } & \multirow{2}{*}{$\begin{array}{l}\text { Number } \\
\text { plants } \\
\text { tested }\end{array}$} & \multirow{2}{*}{$\begin{array}{l}\text { Number } \\
\text { PCR } \\
\text { positive }\end{array}$} & \multicolumn{6}{|c|}{ Number of plants positive for each organism/s categorised by symptoms } \\
\hline & & & $\mathrm{RLO}^{\mathrm{A}}$ & $\begin{array}{l}\text { Ca. P. australiense } \\
\text { AGY }^{\mathrm{B}} \text { strain }\end{array}$ & $\begin{array}{l}\text { Ca. P. australiense } \\
\text { PYL }^{\mathrm{C}} \text { variant } \\
\text { strain }\end{array}$ & $\begin{array}{l}\text { RLO and } C a . \mathrm{P} . \\
\text { australiense } \\
\text { AGY strain }\end{array}$ & $\begin{array}{l}\text { TBB and } C a . P . \\
\text { australiense } \\
\text { AGY strain }\end{array}$ & $\mathrm{TBB}^{\mathrm{D}}$ \\
\hline $\mathrm{SLY}^{\mathrm{E}}$ & 363 & 211 & 117 & 67 & 11 & 11 & 3 & 2 \\
\hline SLY \& SGPF & 12 & 12 & - & 12 & - & - & - & - \\
\hline SGP & 2 & 2 & - & 2 & - & - & - & - \\
\hline $\mathrm{SFD}^{\mathrm{G}}$ & 7 & 1 & - & 1 & - & - & - & - \\
\hline $\mathrm{SLF}^{\mathrm{H}}$ & 20 & 4 & - & - & - & - & - & 4 \\
\hline Asym $^{\mathrm{I}}$ & 114 & 20 & 20 & - & - & - & - & - \\
\hline
\end{tabular}

${ }^{A}$ RLO, Rickettsia-like-organism. ${ }^{B}$ AGY, Australian grapevine yellows. ${ }^{C}$ PYL, Phormium yellow leaf. ${ }^{\mathrm{D}} \mathrm{TBB}$, Tomato big bud. ${ }^{\mathrm{E}} \mathrm{SLY}$, strawberry lethal yellows. ${ }^{\mathrm{F}} \mathrm{S}$ GP, strawberry green petal. ${ }^{\mathrm{G}} \mathrm{SFD}$, strawberry fruit distortion. ${ }^{\mathrm{H}} \mathrm{SLF}$, strawberry leaves from fruit. ${ }^{\mathrm{I}}$ Asym, Asymptomatic.

phytoplasma with $C a$. P. australiense AGY strain (Table 2). The PYL variant strain of $C a$. P. australiense was detected in 11 plants (Table 2). There was a significant relationship between all agents and SLY diseased plants $(P<0.0001)$. The relationship between SLY disease and the RLO was significant $(P=0.002)$ as was the relationship between SLY disease and the phytoplasmas $(P<0.0001)$. Only 12 plants were observed with symptoms of both SLY and SGP and all these were positive for $\mathrm{Ca}$. P. australiense AGY strain (Table 2). This phytoplasma was also detected in the two plants observed with SGP disease (Table 2).

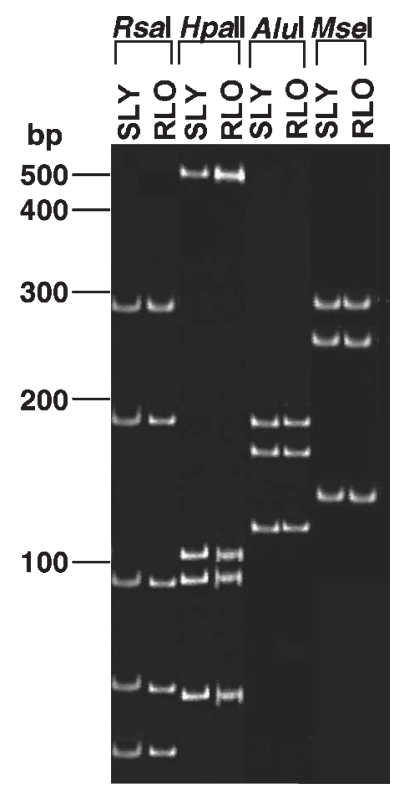

Fig. 1. RFLP analysis of PCR products of a representative sample amplified with the PBTF1/PBTR1 primers specific for the $s d h A$ gene of the RLO associated with strawberry lethal yellows disease. SLY, strawberry lethal yellows; RLO, the $s d h A$ gene of an RLO associated with strawberry lethal yellows that shared 96\% homology with the corresponding gene of the papaya bunchy top RLO.
A new symptom called strawberry fruit distortion (SFD) was observed in seven plants and one of these plants was PCR positive, that phytoplasma being $C a$. P. australiense AGY strain (Table 2). Fruits on these plants were enlarged, green and white, and seedless. Another new symptom called strawberry leaves from fruit (SLF) was observed in 20 plants (Fig. 2). Four of these plants were PCR positive and in all cases the agent was the TBB phytoplasma (Table 2).

In the Queensland runner and fruit production areas, SLY disease was observed more often than any of the other diseases and in a wide range of cultivars (Table 3). SGP was only ever observed in the fruit production areas (Table 3 ).

The RLO associated with SLY disease was detected at Stanthorpe, Nambour and Caboolture. Ca. P. australiense Australian strain was identified in SLY diseased plants collected at the same locations as the RLO but also at Beenleigh and Adelaide, South Auatralia (Table 3). The

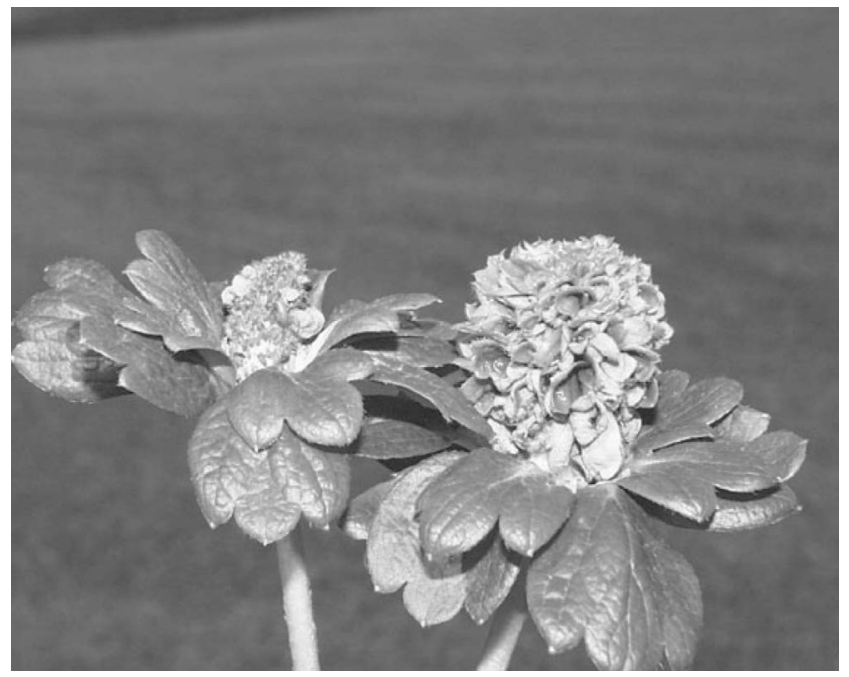

Fig. 2. Strawberry leaves from fruit (SLF) exhibited by strawberry plants collected in Queensland. 


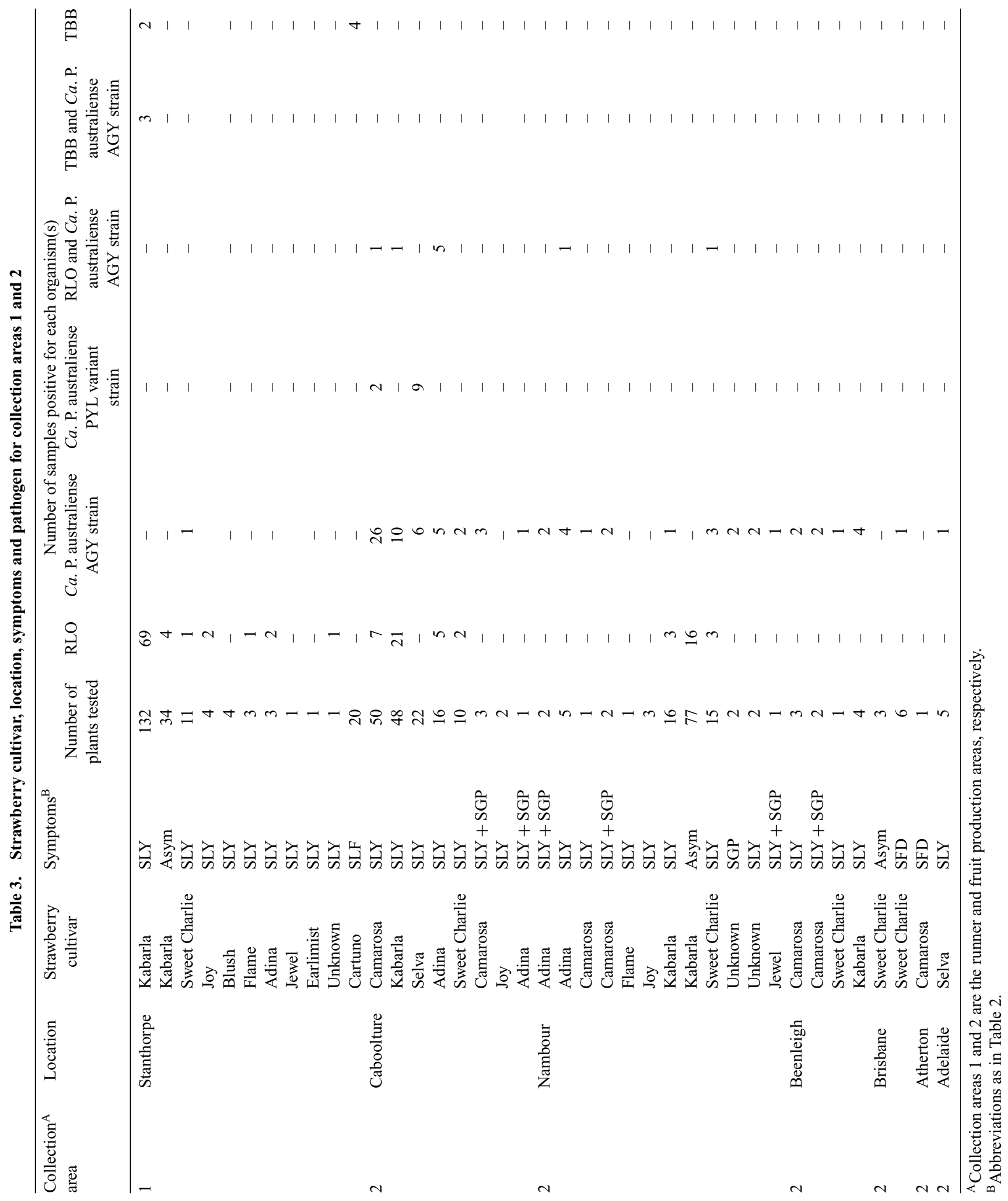


$C a$. P. australiense PYL variant strain was amplified from SLY diseased plants collected at one location on the same day (Table 3). An RLO and a phytoplasma were detected together in nine SLY diseased plants collected from Nambour and Caboolture. The RLO and phytoplasma were detected in the same plants with SLY disease at Nambour and Caboolture (Table 3). The TBB phytoplasma was associated with SLY and SLF diseases in the Stanthorpe area, and $C a$. P. australiense AGY strain with SFD disease in Brisbane, Queensland (Table 3).

The RLO was the agent identified most often in SLY diseased plants collected on the runner production farms near Stanthorpe for the years 2000, 2001 and 2002 (Fig. 3). In 2000, the RLO was the most prevalent agent on fruit production farms but in 2001 and 2002, phytoplasmas were detected most often in plants with SLY disease (Fig. 3).

\section{Discussion}

\section{Testing of PBT RLO sdhA PCR primers on SLY samples}

The nucleotide sequence of the product amplified from SLY diseased samples using the PBTF1 and PBTR1 primers shared $96 \%$ similarity with the $s d h A$ gene of the PBT RLO which indicates that the corresponding gene was amplified from SLY diseased samples. This suggests that the primers designed by Davis et al. 1998 should be suitable for screening SLY diseased plants for an RLO. However, only one gene was characterised so it was not possible to confirm that the bacterium associated with SLY is definitely of Rickettsiae origin and future studies may show that a bacterium-likeorganism is associated with SLY disease.

\section{SLY and SGP diseases}

Greber and Gowanlock (1979) previously reported the occurrence of RLO-associated SLY symptoms and phytoplasma-associated SLY symptoms. Bronze discoloration of older leaves, stunted petioles and interveinal chlorosis on younger leaves are symptoms associated with a rickettsia-like-organism (RLO) (Greber and Gowanlock 1979). Purple discoloration of older leaves, stunted younger leaves with shortened petioles and marginal chlorosis are associated with a phytoplasma. The SLY diseased plants collected during this study exhibited a combination of these two SLY symptom types. Due to this, the diseased strawberry samples collected during this study could not be classified into either RLO or phytoplasma associated SLY symptoms. These findings suggest that the type of SLY symptoms exhibited by the strawberry plant may be influenced by soil type or cultivar instead of the presence or absence of a pathogen.

In this study, the majority of diseased strawberry plants had lethal yellows symptoms, a few had green petal disease, and strawberry plants with both lethal yellows and green petal diseases were observed in fruit production areas for the first time. All strawberry plants with SGP disease alone or in combination with SLY disease were positive for $\mathrm{Ca}$. P. australiense AGY strain which suggests that SGP symptoms are always indicative of a phytoplasma association. For SLY disease, there was a significant association between putative causal agents and disease and, as reported previously, Ca. P. australiense (AGY strain), Ca. P. australiense (PYL variant strain), the tomato big bud (TBB) phytoplasma and a RLO were associated with SLY disease (Padovan et al. 2000).

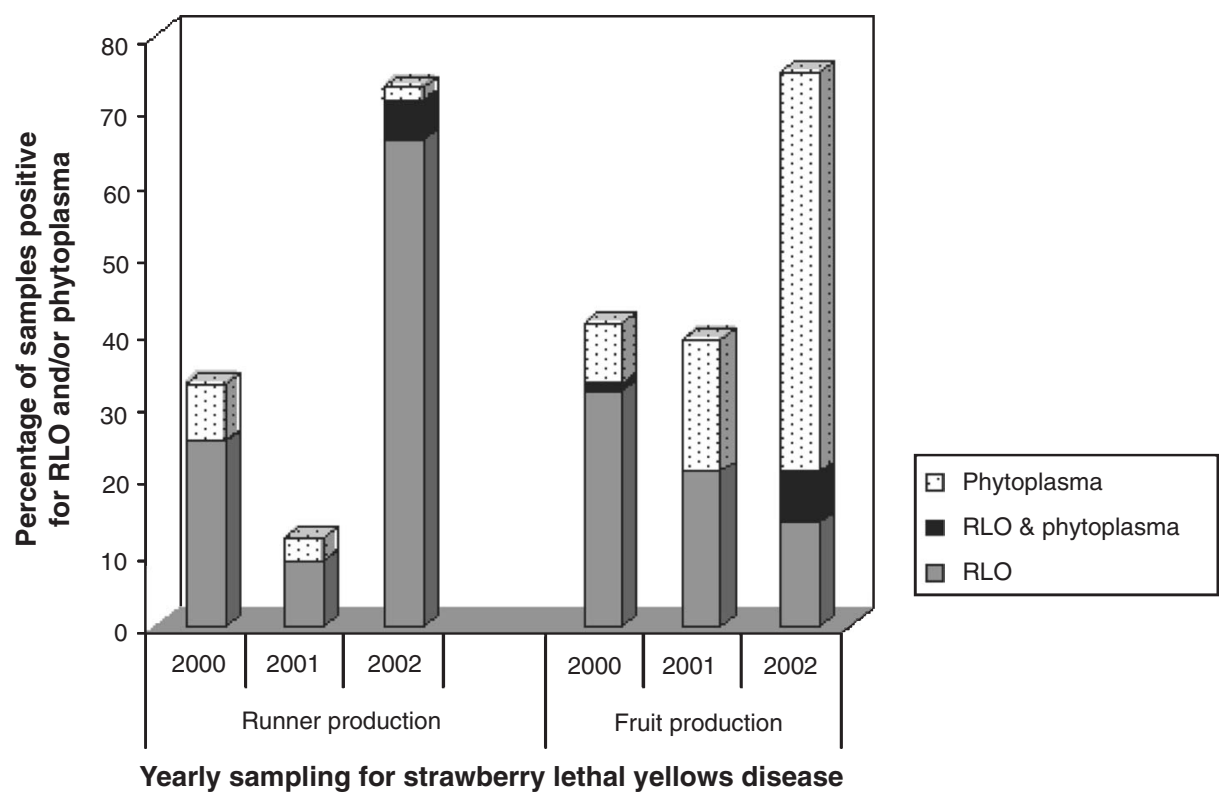

Fig. 3. The association of RLO and phytoplasmas with strawberry lethal yellows diseases between March 2000 and October 2002. 
Although there was a significant association between SLY disease and RLO or phytoplasmas, not every plant with SLY disease was positive for these organisms.

A major factor may have been low titre and uneven distribution of the phytoplasmas and RLO in the host plant (Constable et al. 2003; Gibb et al. 1999). Furthermore, another organism, which has not yet been characterised, may be associated with SLY disease.

The tuf gene amplified from 11 plants with SLY disease collected from Caboolture in 2001 had the same RFLP banding pattern as the PYL phytoplasma when digested with HpaII but had a unique banding pattern when digested with HindIII. This phytoplasma was designated $\mathrm{Ca}$. P. australiense PYL variant strain. The PYL phytoplasma is associated with New Zealand strawberry lethal yellows and Phormium yellow leaf (PYL) diseases (Andersen et al. $1998 a, 1998 b$ ). Although the phytoplasma associated with PYL disease can be differentiated from the Australian SLY phytoplasma by tuf gene analysis (Schneider et al. 1997), these two phytoplasmas are considered identical based on 16S rRNA gene analysis and, therefore, both are designated Ca. P. australiense (Padovan et al. 2000; Liefting et al. 1998). The $\mathrm{Ca}$. P. australiense PYL variant strain was associated only with SLY diseased samples collected at Caboolture on the same day and from the same farm. Its absence from other farms in the Caboolture area may indicate that the vector was not present throughout the region to transmit the phytoplasma more widely or an itinerant vector carrying $\mathrm{Ca}$. P. australiense PYL variant strain from another region and/or another host made a brief stop to feed on a limited number of plants in the area (Lee et al. 2003, 1998). Disease surveys of alternative host plants in the strawberry growing areas may provide insight into the movement of the vector for this phytoplasma and the distribution of the phytoplasma which would indicate whether this farm represents an isolated ecological niche for the $C a$. P. australiense PYL variant strain.

Few plants with SLY disease were positive for multiple agents. One explanation is that the frequency of multiple 'infections' may have been greater than the results showed with the limitation being PCR, which preferentially amplifies the dominant species (Lee et al. 2000). Mixed 'infections' are more frequently revealed when samples are screened using nested PCR (Alma et al. 1996; Lee et al. 1995) but this has other drawbacks such as risk of contamination and expense.

It is unlikely that strawberry cultivar had an effect on symptom expression because plants of the same cultivar exhibited green petal, lethal yellows, and a combination of both symptoms. Green petal disease was observed only at the fruit production farms; therefore, the age of the plant at the time of inoculation or soil type may influence symptom expression. In addition, plants for runner production do not flower, which limits the opportunity for
SGP disease expression in the runner region. This study did not resolve the issue of why the same phytoplasma is associated with two different symptoms, green petal and lethal yellows.

\section{New strawberry disease symptoms}

Two previously unreported strawberry disease symptoms, severe fruit distortion (SFD) and strawberry leaves on fruit (SLF) were observed during the study. Unlike lethal yellows symptoms, which were observed over the 3 year study, the SFD and SLF diseases were recorded only once during the study. Of the seven samples with SFD, one was positive for $\mathrm{Ca}$. P. australiense AGY strain and of the $20 \mathrm{SLF}$ samples, four were positive for the TBB phytoplasma. The sample size was too small to make inferences about disease and phytoplasma association but it was interesting to observe the range of symptoms in the field. The SFD and SLF symptoms may have been caused by other factors such as nutritional deficiencies, poor pollination, inherited characteristics, spray drift or another pathogen that was not detected. The plants that tested positive for phytoplasma may have shown symptoms of SLY or SGP disease if they had been sampled later.

\section{Causal agent and locality of diseased strawberry plants}

SLY disease is the only RLO-associated disease identified in Australia. An RLO is also associated with papaya bunchy top disease in North America (Davis et al. 1998) and carrot proliferation disease in the Czech Republic (Franova et al. 2000). Very little is known about the distribution and occurrence of RLO-associated plant diseases. In this study, the RLO was detected most often in plants with SLY disease in the runner production area while at the fruit production farms, the proportion of disease associated with phytoplasmas increased from 2000, until by 2002, phytoplasmas were much more common than RLOs. This finding suggests that although the RLO-associated SLY disease is distributed throughout Queensland strawberry growing districts, this organism is more frequently identified in the runner production area. Based on RFLP analysis of the $s d h A$ gene amplified from the SLY diseased samples collected at both runner and fruit production farms, the same RLO strain was present in the different strawberry growing regions. However, it is not known whether the $s d h A$ gene is suitable for differentiating RLOs. The characterisation of the SLY RLO $16 \mathrm{~S}$ rRNA gene that has variable and non-variable regions may facilitate the differentiation of the RLOs associated with SLY disease.

In Australia, the vector for the SLY RLO has not yet been identified whereas in North America the leafhopper, Empoasca papayae, is known to transmit the RLO associated with papaya bunchy top disease. The only species of Empoasca sensu stricto from Australia is Empoasca smithi (Murray Fletcher, personal communication); this leafhopper 
may be a possible vector of the SLY RLO. However, other leafhopper genera may also transmit the SLY RLO. Identification of other host plants for the SLY RLO may provide insight into the nature of insect vectors for this organism and indicate reasons why RLO-associated SLY disease is more common in the runner production area.

\section{Acknowledgements}

This research was supported by the Cooperative Research Centre for Tropical Plant Protection, Brisbane, Australia, and the Better Berries Program, Queensland Department of Primary Industries, and Fisheries, Nambour, Australia. We thank Queensland strawberry growers for allowing us to collect samples from their farms, and Neil Greer for project support. We thank Dr Murray Fletcher (NSW Agricultural Scientific Collections Unit, Orange, Australia) for providing information regarding Australian leafhoppers.

\section{References}

Alma A, Davis RE, Vibio M, Danielli A, Bosco D, Arzone A, Bertaccini A (1996) Mixed infection of grapevines in northern Italy by phytoplasmas including 16S rRNA RFLP subgroup 16SrI-B strains previously unreported in this host. Plant Disease 80, 418-421.

Altschul SF, Madden TL, Schäffer AA, Zhang J, Zhang Z, Miller W, Lipman DJ (1997) Gapped BLAST and PSI-BLAST: a new generation of protein database search programs. Nucleic Acids Research 25, 3389-3402. doi: 10.1093/nar/25.17.3389

Andersen MT, Beever RE, Gilman AC, Liefting LW, Balmori E, Beck DL, Sutherland PW, Bryan GT, Gardner RC, Forster RLS (1998a) Detection of Phormium yellow leaf phytoplasma in New Zealand flax (Phormium tenax) using nested PCRs. Plant Pathology 47, 188-196. doi: 10.1046/j.1365-3059.1998. 00209.x

Andersen MT, Longmore J, Liefting LW, Wood GA, Sutherland PW, Beck DL, Forster RLS (1998b) Phormium yellow leaf phytoplasma is associated with strawberry lethal yellows disease in New Zealand. Plant Disease 82, 606-609.

Broadley RH, Waite GK, Gage J, Greber RS (1988) 'Strawberry pests.' (Department of Primary Industries, Queensland Government: Brisbane)

Constable FE, Gibb KS, Symons RH (2003) Seasonal distribution of phytoplasmas in Australian grapevines. Plant Pathology 52, 267-276. doi: 10.1046/j.1365-3059.2003.00849.x

Davis MJ, Ying Z, Brunner BR, Pantoja A, Ferwerda FH (1998) Rickettsial relative associated with papaya bunchy top disease. Current Microbiology 36, 80-84. doi: 10.1007/ s002849900283

Deng S, Hiruki C (1991) Amplification of 16S rRNA genes from culturable and non-culturable Mollicutes. Journal of Microbiological Methods 14, 53-61. doi: 10.1016/0167-7012(91) 90007-D

Doyle JJ, Doyle JL (1990) Isolation of plant DNA from fresh tissue. Focus (San Francisco, Calif.) 12, 13-15.
Franova J, Karesova R, Varatil M, Simkova M, Valova P, Nebesarova J (2000) A carrot proliferation disease associated with rickettsia-like organisms in the Czech Republic. Journal of Phytopathology 149, 53-55. doi: 10.1046/j.1439-0434.2000.00465.x

Gibb KS, Constable F, Moran J, Padovan AC (1999) Phytoplasmas in Australian grapevines - detection, differentiation and associated diseases. Vitis 38, 107-114.

Greber RS (1987) Strawberry Rickettsia yellows and mycoplasma yellows. In 'Virus diseases of small fruit.' (United States Department of Agriculture)

Greber RS, Gowanlock DH (1979) Rickettsia-like and Mycoplasma-like organisms associated with two yellow-type diseases of strawberries in Queensland. Australian Journal of Agricultural Research 30, 1101-1109. doi: 10.1071/AR9791101

Lee I-M, Bertaccini A, Vibio M, Gundersen DE (1995) Detection of multiple phytoplasmas in perennial fruit trees with decline symptoms in Italy. Phytopathology $\mathbf{8 5}, 728-735$.

Lee I-M, Davis RE, Gundersen-Rindal DE (2000) Phytoplasmas: Phytopathogenic mollicutes. Annual Review of Microbiology 54 221-255. doi: 10.1146/annurev.micro.54.1.221

Lee I-M, Gundersen-Rindal DE, Bertaccini A (1998) Phytoplasma: ecology and genomic diversity. Phytopathology 88, 1359-1366.

Lee I-M, Martini M, Bottner KD, Dane RA, Black MC, Troxclair N (2003) Ecological implications from a molecular analysis of phytoplasmas involved in an aster yellows epidemic in various crops in Texas. Phytopathology 93, 1368-1377.

Liefting LW, Padovan AC, Gibb KS, Beever RE, Andersen MT, Newcomb RD, Beck DL, Forster RLS (1998) 'Candidatus Phytoplasma australiense' is the phytoplasma associated with Australian grapevine yellows, papaya dieback and Phormium yellow leaf diseases. European Journal of Plant Pathology 104, 619-623. doi: 10.1023/A:1008693904427

Lorenz K-H, Schneider B, Ahrens U, Seemüller E (1995) Detection of the apple proliferation and pear decline phytoplasmas by PCR amplification of ribosomal and nonribosomal DNA. Phytopathology 85, 771-776.

Padovan AC, Gibb KS, Bertaccini A, Magarey PA, Sears BB (1995) Molecular detection of the Australian grapevine yellows phytoplasma and comparison with grapevine yellows phytoplasma from Italy. Australian Journal of Grape and Wine Research 1, $25-31$.

Padovan AC, Gibb KS, Persley D (2000) Association of 'Candidatus Phytoplasma australiense' with green petal and lethal yellows disease in strawberry. Plant Pathology 49, 362-369. doi: 10.1046/j.1365-3059.2000.00461.x

Schneider B, Gibb KS (1997) Detection of phytoplasma in declining pears in southern Australia. Plant Disease 81, 254-258.

Schneider B, Gibb KS, Padovan AC (1997) Sequence and RFLP analysis of the elongation factor $\mathrm{Tu}$ gene used in differentiation and classification of phytoplasmas. Microbiology 143, 3381-3389.

Schneider B, Seemüller E, Smart CD, Kirkpatrick BC (1995) Phylogenetic classification of plant pathogenic mycoplasma-like organisms or phytoplasmas. Molecular and Diagnostic Procedures in Mycoplasmology 1, 369-380.

Received 25 June 2004, accepted 7 October 2004 